\title{
DETERMINAN DAN KONSEKUENSI PENGUNGKAPAN LINGKUNGAN
}

\author{
Vivian Angelina Soegiharto Wibowor), Teodora Winda Mulia ${ }^{2)}$ \\ ${ }^{1,2)}$ Magister Akuntansi, Universitas Katolik Widya Mandala Surabaya \\ viviangelina96@gmail.com \\ winda@ukwms.ac.id
}

Diterima 15 Februari 2020 / Disetujui 29 Agustus 2020

\begin{abstract}
The rampant cases of forest fires in Indonesia caused by business operations, make the company more and more highlighted by the public, so the companies are encouraged to make extensive environmental disclosure, which shows the determinant factors such as environmental performance has been carried out by the company well. The more extensive disclosure of environmental performance can provide greater opportunities at the dimension of corporate sustainability as a consequence of the disclosure made. This study was conducted to analyze the mediating role of environmental disclosure on the relationship of environmental performance to the dimention of corporate sustainability. The sample used in this study was obtained by purposive sampling method are non-financial sector companies listed on the Indonesia Stock Exchange in 2015-2018, obtained PROPER ratings in 2015-2017, and no losses. The testing and analysis techniques used are multiple regression techniques and path analysis. Testing in this study produce evidences that environmental performance is able to influence the dimension of corporate sustainability directly and indirectly, that mediated by environmental disclosure. Then, this study also showed an evidence that environmental performance is able to influence environmental disclosure, and environmental disclosure is able to directly affect the dimension of company sustainability.Result of this study showed several implications are, for non-financial companies that sensitive to the environmental, is better to start managing the environmental well, for example doing the environmental performance, such as manage the waste of factory and then disclose the performance results fullest. This is able to provide some important information for stakeholders and policy makers as additional references to make a decision and design the environmental laws.
\end{abstract}

Keywords: Environmental Performance, Environmental Disclosure, Corporate Sustainability

\begin{abstract}
ABSTRAK : Maraknya kasus pembakaran hutan di Indonesia yang disebabkan karena operasi usaha, membuat perusahaan semakin banyak disorot oleh publik, sehingga perusahaan didorong untuk melakukan pengungkapan lingkungan yang luas, yang menunjukan faktor determinan seperti kinerja lingkungan telah dilakukan oleh perusahaan dengan baik. Adanya pengungkapan mengenai kinerja lingkungan yang semakin luas dapat memberikan peluang yang lebih besar pada dimensi sustainability perusahaan sebagai konsekuensi dari pengungkapan yang dilakukan. Penelitian ini dilakukan untuk menganalisis peran mediasi dari pengungkapan lingkungan pada hubungan kinerja lingkungan terhadap dimensi keuangan sustainability perusahaan. Penggunaan sampel pada penelitian ini diperoleh dengan metode purposive sampling yaitu perusahaan sektor non keuangan yang terdaftar dalam Bursa Efek Indonesia tahun 2015-2018, memperoleh peringkat PROPER pada tahun 2015-2017, dan tidak mengalami kerugian. Teknik pengujian dan analisis yang digunakan yaitu teknik regresi berganda dan analisis jalur. Pengujian pada penelitian ini menghasilkan bukti bahwa kinerja lingkungan mampu mempengaruhi dimensi sustainability perusahaan, baik secara langsung, maupun secara tidak langsung, yaitu dengan dimediasi oleh pengungkapan lingkungan. Selain itu, penelitian ini juga menghasilkan bukti bahwa kinerja lingkungan mampu mempengaruhi pengungkapan lingkungan, dan pengungkapan lingkungan mampu mempengaruhi dimensi sustainability perusahaan secara langsung. Hasil dari penelitian ini menunjukan beberapa implikasi antara lain, bagi perusahaan non-keuangan yang sensitif terhadap lingkungan, sebaiknya mulai melakukan pengelolaan lingkungan dengan baik misalnya melakukan kinerja lingkungan seperti melakukan pengelolaan limbah pabrik serta mengungkapkan hasil
\end{abstract}


kinerja tersebut seluas-luasnya. Hal ini mampu memberikan informasi penting bagi stakeholder dan pembuat kebijakan sebagai referensi tambahan dalam pengambilan keputusan serta pembentukan Undang-undang mengenai lingkungan.

Kata Kunci: Kinerja Lingkungan, Pengungkapan Lingkungan, Sustainability Perusahaan

\section{Pendahuluan \\ Latar Belakang}

Bencana di Indonesia banyak diakibatkan oleh banyaknya operasi bisnis yang melibatkan alam seperti yang diungkapkan oleh Pratama dan Kandi (2015) dalam CNN Indonesia bahwa:

"Sejumlah perusahaan diduga melakukan pembakaran hutan dengan sengaja agar bisa lebih cepat membuka lahan untuk menanam sawit ... setidaknya 1,67 juta hektar lahan hutan terbakar, menyisakan asap yang mengganggu pernapasan, proses pendidikan, perekonomian, hingga transportasi”.

Berdasarkan kutipan diatas, bencana paling banyak timbul akibat operasi bisnis perusahaan yaitu polusi udara akibat pembakaran hutan. Kementerian Lingkungan Hidup dan Kehutanan (KLHK) melihat hal tersebut dan melakukan penegakan hukum atas kerusakan alam yaitu hukum administrasi, hukum pidana dan serta hukuman perdata. Hukum administrasi merupakan hukum yang paling banyak dikeluarkan karena banyak perusahaan yang memiliki perizinan lingkungan, namun tidak memiliki hal-hal terkait penggunaan lingkungan antara lain, kepemilikan peralatan pemadam kebakaran, kecukupan sumber daya manusia yang menangani, dan adanya sistem pemantauan.

Perusahaan yang tidak memiliki hal-hal yang ada dalam izin mereka, maka perusahaan diminta oleh KLHK untuk memenuhi ketentuan, dan pada saat itu, operasi bisnis perusahaan akan diberhentikan untuk sementara waktu. Konsekuensi terburuk ketika perusahaan tidak melakukan pemenuhan kebutuhan yang telah dicantumkan dalam izin usaha, maka izin perusahaan akan dibekukan, bahkan dicabut.

Banyaknya izin yang dicabut dan dibekukan akibat aktivitas operasi perusahaan pada kasus pembakaran hutan dan lahan mulai tahun 2015 hingga awal 2019 telah mencapai 171 sanksi administrasi, 11 gugatan perdata, dan 510 kasus pidana (Dewi dkk., 2019). Pada tahun 2015 , terdapat beberapa perusahaan yang memperoleh sanksi administrasi atas kasus pembakaran hutan dan lahan (Pratama \& Kandi, 2015; www.halloriau.com, 2015), antara lain:

1. PT HSL, PT SRT, PT DPI (Riau) yang terkena sanksi pencabutan hak penguasaan hutan;

2. PT DHL (Jambi) dan PT MAS (Kalimantan Barat) terkena sanksi pencabutan izin lingkungan;

3. PT BMH, PT SWI, PT WAJ, PT RPP, PT TPR, PT SBA (Sumatera Selatan); PT SRL dan PT LIH (Riau), PT PBP (Jambi) terkena sanksi pembekuan izin.

Tidak hanya itu saja, pada tahun 2019 kasus yang sama juga menyeret 11 perusahaan Indonesia dimana hal tersebut menyebabkan kerugian bagi negara dengan total kerugian sebesar $\mathrm{Rp}$ 18,3 triliun (Dewi., dkk, 2019). Kesebelas perusahaan yaitu PT Kalista Alam, PT Merbabu Pelalawan Lestari, PT Nasional Sago Prima, PT Jatim Jaya Perkasa, PT Waringin Agro Jaya, PT Ricky Kurniawan Kertapersada, PT Bumi Mekar Hijau, PT Waimusi Agroindah, PT Palmina Utama, PT Agro Tumbuh Gemilang Abadi, dan PT Surya Panen Subur yang melakukan pembakaran hutan dan kerusakan hutan (Dewi., dkk, 2019). Kerusakan alam akibat operasi perusahaan tidak hanya terjadi karena pembakaran hutan dan lahan saja, namun pertambangan turut mendukung kerusakan lingkungan pula.

Pada tahun 2019, Jaringan Advokasi Tambang atau JATAM bersama dengan organisasi lingkungan lainnya mendesak pemerintah provinsi Sulawesi Selatan melalui Gubernur, Menteri Lingkungan Hidup, Menteri Energi dan Sumber Daya 
Mineral (ESDM), dan Menteri Kelautan dan Perikanan (KKP) untuk mencabut dan membatalkan semua izin pertambangan di Pulau Wawonii, Kabupaten Konawe Kepulauan, Provinsi Sulawesi Tenggara. Hal ini dikarenakan, pada lokasi tersebut yaitu pulau Wawaonii, PT Gema Kreasi Perdana melakukan penerobosan alat berat untuk proses pertambangan yang dapat merusak lahan pulau ketika izinnya sedang dibekukan oleh Pemerintah Provinsi Sulawesi Tenggara atas dasar hukum UU nomor 27 tahun 2007 tentang perlindungan wilayah pesisir dan pulau-pulau kecil (JATAM, 2019). Pembekuan izin juga dilakukan oleh Gubernur Sulawesi Tenggara kepada 5 perusahaan selain PT Gema Kreasi Perdana antara lain PT Alotma Karya, PT Konawe Bakti Pratama, PT Kimco Citra Mandiri, dan PT Bumi Konawo Mining (JATAM, 2019).

Banyaknya kasus perusakan lingkungan akibat kegiatan operasi bisnis dapat menyeret beberapa perusahaan untuk memperoleh berbagai macam hukuman yang dinilai mampu mempengaruhi kestabilan perusahaan dalam mempertahankan bisnis mereka. Contohnya karyawan PT Bumi Mekar Hijau dan PT Sebangun Bumi Andalas sebanyak 1.400 orang merasa khawatir akan masa depan kehidupan mereka karena semenjak perusahaan dibekukan oleh Kementerian Lingkungan Hidup dan Kehutanan akibat pembakaran hutan dan lahan, perusahaan sudah tidak beroperasi lagi semenjak Oktober 2015 yang mengancam terjadinya pemutusan hubungan kerja secara besarbesaran kepada karyawannya (Saputra, 2016). Selain PT Bumi Mekar Hijau dan PT Sebangun Bumi Andalas, kerusakan lingkungan akibat operasi bisnis juga menghancurkan masa depan PT Rayon Utama Makmur (PT RUM) yang ada di Kabupaten Sukoharjo, Jawa Tengah. Perusahaan tersebut terpaksa menutup kegiatan operasionalnya karena tidak dapat melakukan pengelolaan limbah rayon dengan benar dimana limbah tersebut dibuang ke sungai dan menghasilkan bau busuk (Kusumo, 2018). Hal tersebut mampu merugikan warga disekitar pabrik terutama limbah cair yang dapat membahayakan kesehatan warga bahkan sampai dengan pencemaran lahan pertanian akibat air irigasi yang tercemar limbah pabrik (Kusumo, 2018).

Contoh-contoh diatas menunjukan bahwa setiap kegiatan yang dilakukan perusahaan yang berkaitan dengan alam, mampu mempengaruhi dimensi sustainability perusahaan (Pratama \& Kandi, 2015). Maksud dari sustainability perusahaan yaitu pembangunan berkelanjutan. Keberlanjutan perusahaan dapat terbentuk ketika perusahaan berupaya memenuhi kebutuhan saat ini tanpa mengurangi kemampuan sumber daya masa depan, yang digunakan untuk memenuhi kebutuhannya di masa yang akan datang (Supriyadi, 2013). Perlakuan ini dilakukan untuk membuat perusahaan mampu hidup terus menerus di periode-periode berikutnya untuk membuat perusahaan lebih berkembang lagi dan mengurangi tingkat resiko kematian perusahaan apapun penyebabnya, termasuk masalah lingkungan. Maka dari itu, untuk menjaga kestabilan usaha dan meningkatkan kemampuan sustainability perusahaan, penting adanya kegiatan bisnis perusahaan selain kegiatan bisnis utama yaitu memperbaiki, merawat dan menjaga lingkungan di tempat perusahaan itu beroperasi. Kegiatan itulah yang dapat disebut sebagai kinerja lingkungan.

Upaya peningkatan kinerja lingkungan juga dilakukan oleh Kementerian Lingkungan Hidup dengan mengadakan program pemeringkatan kinerja lingkungan untuk mendorong perusahaan-perusahaan di Indonesia melakukan perbaikan alam sebagai upaya timbal balik atas sumber daya yang telah disediakan oleh alam tersebut (Tjahjono, 2013). Program kementerian tersebut dinamakan dengan Program Peringkat Kinerja Perusahaan dalam Pengelolaan Lingkungan Hidup (PROPER) yang diundangkan dalam Peraturan Menteri Lingkungan Hidup Republik Indonesia nomor 6 tahun 2013.

Nyatanya, masih banyak para pemangku kepentingan yang kurang mengetahui dan memahami kinerja lingkungan (Nurleli \& Faisal, 2016). Oleh karena itu, penting adanya pengungkapan 
mengenai kegiatan pemeliharaan lingkungan yang telah dilakukan perusahaan atau lebih dikenal dengan istilah pengungkapan lingkungan, sebagai mediasi dalam menyampaikan informasi dimana informasi tersebut dapat digunakan untuk meningkatkan pengetahuan stakeholder atas perusahaan (Nurleli \& Faisal, 2016). Adanya pengungkapan lingkungan juga dapat digunakan perusahaan untuk meningkatkan image dan kepercayaan dimata para stakeholder (Rohmah \& Wahyudin, 2015). Image yang terbentuk mampu menimbulkan kepercayaan stakeholder dimana, hal tersebut dapat memberikan dampak yang baik bagi perusahaan seperti peningkatan dimensi sustainability perusahaan (Tjahjono, 2013).

Semua stakeholder akan melakukan pengambilan keputusan yang didasarkan dengan informasi-informasi yang disediakan oleh perusahaan, baik itu berupa laporan yang bersifat keuangan maupun laporan non-keuangan seperti corporate social responsibility report atau sustainabillity report. Penggunaan informasi tersebut diyakini oleh stakeholder bahwa perusahaan telah melakukan dan melaporkan kinerjanya yang didasarkan pada teori stakeholder, dimana teori tersebut berisikan teori pembentukan moral serta nilai yang dapat digunakan oleh perusahaan untuk menjadi landasan dalam melaksanakan kegiatan usahanya (Freeman dkk., 2010, p. 12).

Sebagai sebuah landasan, teori ini dibentuk dengan tujuan yaitu untuk membantu manajemen dalam berperilaku sebagai operator bisnis agar mampu memberikan dampak baik kepada perusahaan serta stakeholder-nya karena perusahaan akan memiliki keberlangsungan hidup yang panjang, pasti tidak akan lepas dari bantuan para stakeholder-nya (Burgwal \& Vieira, 2014). Oleh karena itu, perusahaan yang menerapkan teori ini akan berusaha untuk melakukan aktivitas bisnis mereka dengan disesuaikan pada kebutuhan dan keinginan stakeholder pula.

Banyak masyarakat yang lebih memahami legitimasi sebagai sebuah gambaran atas pemikiran serta persepsi yang timbul dalam benak masing-masing orang, yang terbentuk akibat tindakan pengelolaan perusahaan yang dinilai pantas dan mampu diterima karena telah dilakukan dengan berdasarkan pada norma, nilai, serta kepercayaan yang timbul dan berkembang di dalam lingkungan masyarakat (Amri, 2015). Adanya persaingan usaha yang ketat, penting bagi perusahaan untuk memperoleh legitimasi masyarakat karena dengan adanya legitimasi dari para masyarakat, perkembangan dan keberlanjutan perusahaan akan lebih terjamin (Pertiwi, 2015).

Legitimasi masyarakat dapat lebih mudah diperoleh jika perusahaan menerapkan teori legitimasi, dimana teori ini ada untuk membantu perusahaan lebih memahami pentingnya peran dari legitimasi pada hubungan antara masyarakat dengan perusahaan. Teori legitimasi sendiri merupakan sebuah bentuk pemikiran yang menunjukan keterkaitan antara perusahaan dengan masyarakat yang dibentuk karena adanya kontrak sosial, yang mengharuskan perusahaan untuk memenuhi kewajibannya, dengan melandaskan nilai-nilai keadilan dalam menyampaikan informasi dan melakukan pengungkapan kegiatan usahanya, serta menunjukan perilaku perusahaan saat menanggapi kelompok kepentingan yang dimilikinya (Hadi, 2011, p. 88).

Sustainability merupakan sebuah topik yang masih dinyatakan kontroversial karena hingga kini masih tidak terdapat definisi yang menjelaskan secara pasti dan baku. Beberapa penelitian mengungkapkan bahwa sustainability dapat diartikan bermacammacam tergantung sudut pandang masingmasing orang. Supriyadi (2013) menyatakan bahwa para ahli mengeneralisasi arti dari sustainability sebagai sebuah kemampuan yang dimiliki untuk dapat melangsungkan hidupnya secara statis dan menyiratkan pembangunan yang berkelanjutan. Berdasarkan pada hal itu, maka kini sustainability perusahaan lebih banyak dikenal dengan keberlanjutan perusahaan.

Salah satu dimensi sustainability perusahaan yang paling utama yaitu sisi kinerja keuangannya dimana kinerja tersebut dapat diartikan sebagai hasil yang 
diterima oleh perusahaan dalam suatu periode waktu akibat pengelolaan aset yang dijalankan perusahaan secara efektif (Rudianto, 2013, p. 189). Berdasarkan konsep Triple Bottom Line yang ada memang seharusnya sustainability tidaklah hanya dilihat dari sisi keuangannya, namun juga pengelolaan lingkungan dan interaksi sosial. Kenyataannya, Supriyadi (2013) menemukan pemikiran baru bahwa sisi keuangan merupakan sisi yang paling utama yang harus diperoleh terlebih dahulu agar perusahaan mampu menjalankan sisi kinerja sustainability yang lainnya seperti lingkungan dan sosial di masa depan.

Kinerja merupakan sebuah hasil yang diterima oleh perusahaan selama suatu periode waktu dimana hal tersebut dapat dijalankan dengan berdasarkan tujuan pencarian profit ataupun tidak mencari profit (Fahmi, 2016, p. 137). Ada berbagai macam kinerja di dalam perusahaan yang didasarkan pada sebuah konsep dasar keberlanjutan. Salah satunya yaitu kinerja lingkungan yang jarang sekali memperoleh perhatian dalam perusahaan.

Kinerja lingkungan merupakan hasil yang diperoleh perusahaan atas kinerja yang dilakukan dengan memberikan keadilan dan perhatiannya pada lingkungan di sekitar perusahaan yang telah terkena dampak akibat operasi perusahaan (Hartman \& Desjardins, 2011, p. 442). Kinerja lingkungan wajib dilakukan perusahaan karena adanya operasi perusahaan yang dilakukan, baik secara sadar atau tidak sadar mampu memberikan dampak pada alam lingkungan sekitar perusahaan. Ketika lingkungan yang digunakan rusak, maka hal itu mampu menimbulkan bencana, baik bagi perusahaan maupun masayarakt sekitar.

Corporate social responsibility atau tanggung jawab sosial merupakan sebuah tanggung jawab yang dilakukan oleh perusahaan, dengan memperhatikan sisi sosial yang berhubungan dengan masyarakat dan sisi lingkungan yang berhubungan dengan lingkungan di sekitar perusahaan (Hartman \& Desjardins, 2011, p. 155). Hasil dari kinerja tersebut akan diungkapkan melalui pengungkapan tanggungjawab sosial yang disajikan pada laporan tahunan dimana laporan tersebut nantinya dapat digunakan oleh stakeholder untuk mengambil keputusan atas perusahaan. Salah satu komponen yang berhubungan dengan bencana dalam laporan corporate social responsibility yaitu pengungkapan lingkungan.

Pengungkapan lingkungan yang dikemukakan oleh Pertiwi (2015) merupakan sekumpulan informasi mengenai aktivitas pengelolaan lingkungan yang telah dilakukan perusahaan, yang disajikan dalam laporan tahunan bagian pengungkapan tanggungjawab sosial, baik untuk masa lalu, kini, dan masa depan yang berkaitan dengan pembiayaan dan model kontrol pada lingkungan sekitar. Luasnya pengungkapan lingkungan yang dilakukan oleh perusahaan dapat memberikan peluang yang lebih karena ketika perusahaan memiliki pengungkapan lingkungan yang semakin luas, maka legitimasi stakeholder akan lebih mudah untuk diperoleh. Hal tersebut mampu meningkatan kepercayaan stakeholder yang dapat memberikan peningkatan peluang keberlangsungan karena dengan pengungkapan yang luas, berarti perusahaan tidak menutup-nutupi informasi yang dapat membatasi informasi yang stakeholder butuhkan dalam melakukan pengambilan keputusan.

Berdasarkan beberapa contoh permasalahan lingkungan yang berdampak ada sustainability perusahaan, penelitian ini menggunakan sampel berupa perusahaan terbuka sektor non-keuangan yang terdaftar dalam Bursa Efek Indonesia tahun 20152018, memperoleh peringkat PROPER, dan tidak mengalami kerugian. Alasan digunakan sampel tersebut karena perusahaan sektor non keuangan paling erat hubungannya dengan penggunaan alam dibanding perusahaan sektor keuangan. Sedangkan alasan lain penelitian ini dilakukan karena penelitian terdahulu, seperti penelitian Titisari dan Alviana (2012), Djuitaningsih dan Ristiawati (2011), dan Rohmah dan Wahyudin (2015) masih belum menunjukan kepastian (belum konklusif) atas hubungan kinerja lingkungan terhadap keuangan perusahaan setahun berikutnya yang dapat menunjukan dimensi sustainability. Hal inilah yang 
membuat peneliti menduga adanya peran mediasi dari pengungkapan lingkungan karena berdasarkan teori stakeholder, dimana perusahaan percaya bahwa dimensi sustainability perusahaan tidak akan lepas dari peran stakeholder (Burgwal \& Vieira, 2014). Oleh karena itu, perusahaan akan selalu berusaha untuk menjalin hubungan baik dengan stakeholder, dengan lebih memperhatikan kinerja mereka, khususnya kinerja lingkungan yang akan diungkapkan dalam pengungkapan lingkungan sebagai bukti pertanggungjawaban perusahaan.

\section{Identifikasi Masalah}

Berdasarkan latar belakang diatas, maka masalah yang ingin diteliti yaitu apakah pengungkapan lingkungan mampu menjadi mediasi pada hubungan kinerja lingkungan terhadap dimensi sustainability perusahaan?

\section{Tujuan dan Manfaat}

Tujuan penelitian ini dilakukan yaitu untuk menganalisis pengaruh mediasi pengungkapan lingkungan pada hubungan kinerja lingkungan terhadap dimensi sustainability perusahaan. Selain tujuan, manfaat juga diharapkan dalam penelitian ini yaitu penelitian ini diharapkan dapat dijadikan sebagai penambahan ilmu dan pemikiran bagi penelitian-penelitian selanjutnya mengenai determinan dan konsekuensi dengan adanya pengungkapan lingkungan.

Khususnya bagi perusahaan dan stakeholder hasil penelitian ini juga diharapkan mampu dijadikan referensi ilmu dan pemikiran tambahan bahwa pentingnya peran pengungkapan lingkungan yang mampu meningkatkan image mereka untuk mengungkapkan faktor determinan seperti kinerja lingkungan yang baik, dimana hal tersebut mampu menjadi referensi pertimbangan yang positif dalam pengambilan keputusan. Penelitian ini juga diharapkan mampu menjadi referensi sebagai kajian dasar dalam pembentukan Undang-undang yang mengatur mengenai lingkungan alam oleh pembuat kebijakan.

\section{Pengembangan Hipotesis}

Perusahaan yang melakukan pengungkapan tanggungjawab, khususnya masalah yang sedang marak yaitu masalah kerusakan lingkungan, akan memperoleh reputasi yang tinggi dan berkesempatan untuk memenangkan kompetisi. Hal ini dikarena perusahaan yang melakukan pengungkapan lingkungan memiliki kemampuan untuk melawan perusahaan lain yang mungkin tidak melakukan pengungkapan lingkungan (San dkk., 2015).

Tindakan pengungkapan lingkungan ini akan lebih diapresiasi oleh para stakeholder karena dengan adanya pengungkapan informasi lingkungan, berarti perusahaan telah melakukan tugas dan tanggung jawabnya pada lingkungan sebagai bukti timbal balik. Hal ini membuat stakeholder beranggapan bahwa perusahaan yang mengungkapkan pengungkapan lingkungannya semakin luas, maka perusahaan melakukan lebih banyak kinerja lingkungan dengan memperbaiki, melindungi, dan melestarikan lingkungan dengan baik (Rohmah \& Wahyudin, 2015). Hal ini juga dapat memberikan petunjuk bahwa hasil yang dikeluarkan oleh perusahaan merupakan produk yang ramah lingkungan dan aman penggunaannya, sehingga, dengan semakin luas pengungkapan lingkungan yang dilakukan perusahaan, stakeholder semakin percaya untuk menggunakan produk dan berinvestasi (Nurleli \& Faisal, 2016).

Legitimasi yang diperoleh dari hal tersebut mampu memberikan dampak pada image, pemeroleh penjualan yang semakin meningkat. Peningkatan tersebut dapat memberikan peningkatan kinerja keuangan serta kesuksesan jangka panjang, yang nantinya akan berdampak positif pada dimensi sustainability perusahaan dimasa yang akan datang (San dkk., 2015). Berdasarkan peistiwa tersebut, maka hipotesis yang diajukan adalah:

$\mathrm{H}_{1}$ : Pengungkapan lingkungan berpengaruh positif terhadap dimensi sustainability perusahaan 


\section{Metode Penelitian \\ Pengukuran Variabel}

Penelitian ini menggunakan sebuah variabel dependen yaitu konsekuensi pengungkapan lingkungan berupa dimensi sustainability perusahaan. Dimensi sustainability akan diukur dengan kinerja keuangan yaitu return on assets karena Supriyadi (2013) menemukan pemikiran baru bahwa sisi keuangan merupakan sisi yang paling utama karena jika tanpa adanya keuangan, maka dana yang harus dikeluarkan untuk menjalankan pengelolaan lingkungan dan menciptakan kegiatan sosial di masa depan tidak akan berjalan dengan lancar. Penggunaan periode dalam penelitian ini yaitu satu periode selanjutnya dari periode pelaporan kinerja dan pengungkapan yaitu pada periode 20162018 untuk menunjukan dimensi sustainability perusahaan yang lebih terlihat jangka panjang. Berikut pengukuran sistematis dari ROA (Rohmah \& Wahyudin, 2015):

$$
\text { Return on Assets }(\mathrm{ROA})=\frac{\text { Net Income after Tax }}{\text { Total Assets }}
$$

Tak hanya variabel dependen, variabel independen yang digunakan juga hanya satu yaitu determinan dari pengungkapan lingkungan berupa kinerja lingkungan. Pada penelitian yang dilakukan, pengukuran atas kinerja lingkungan berupa scoring pada peringkat warna yang dikeluarkan Kementerian Lingkungan Hidup dalam kegiatan Program Peringkat Kinerja Perusahaan dalam Pengelolaan Lingkungan Hidup (PROPER) pada periode 2015-2018. Tabel 1 yang akan disajikan dibawah ini menjadi sebuah ringkasan dari kriteria dan penilaian peringkat PROPER.

Tabel 1.Penilaian Peringkat PROPER

\begin{tabular}{lc}
\hline \multicolumn{1}{c}{ Peringkat } & Score \\
\hline Emas & 5 \\
\hline Hijau & 4 \\
\hline Biru & 3 \\
\hline Merah & 2 \\
\hline Hitam & 1 \\
\hline
\end{tabular}

Sumber: Program Penilaian Peringkat Kinerja Perusahaan dalam Pengelolaan Lingkungan. (2013)

Pengungkapan lingkungan yang dijadikan pemediasi dalam penelitian ini diukur dengan menggunakan checklist dengan item pengungkapan yang distandarkan yang akan diberi nilai 0 untuk perusahaan yang tidak melakukan pengungkapan lingkungan sama sekali dan nilai 9 diberikan untuk perusahaan mengungkapkan informasi lingkungannya dengan lengkap pada tabel 2 dibawah ini (Rohmah \& Wahyudi, 2015):

Tabel 2.Item Pengungkapan Lingkungan

\begin{tabular}{|c|c|}
\hline Jenis & Item Pengungkapan \\
\hline $\begin{array}{l}\text { Diskusi } \\
\text { lingkungan }\end{array}$ & \begin{tabular}{lr}
\multicolumn{2}{l}{ Pembicaraan fasilitas, inovasi } \\
produk, proses & usaha yang \\
berhubungan & dengan \\
pengurangan & pencemaran \\
lingkungan &
\end{tabular} \\
\hline $\begin{array}{l}\text { Laporan } \\
\text { lingkungan }\end{array}$ & $\begin{array}{l}\text { Adanya pernyataan } \\
\text { manajemen atas perhatian } \\
\text { lingkungan oleh perusahaan }\end{array}$ \\
\hline $\begin{array}{l}\text { Paparan } \\
\text { tentang } \\
\text { lingkungan }\end{array}$ & $\begin{array}{l}\text { Adanya kebijakan tentang } \\
\text { target, dampak, } \\
\text { manajemen, serta perbaikan } \\
\text { pada lingkungan }\end{array}$ \\
\hline $\begin{array}{l}\text { Peduli } \\
\text { lingkungan }\end{array}$ & $\begin{array}{l}\text { Adanya peran organisasi } \\
\text { untuk merawat lingkungan, } \\
\text { badan legulator lingkungan } \\
\text { serta masyarakat sekitar. }\end{array}$ \\
\hline $\begin{array}{l}\text { Reklamasi } \\
\text { lingkungan }\end{array}$ & $\begin{array}{l}\text { Adanya upaya pencegahan } \\
\text { dan/atau perbaikan atas } \\
\text { kerusakan lingkungan akibat } \\
\text { pengolahan sumber daya alam } \\
\text { oleh perusahaan }\end{array}$ \\
\hline $\begin{array}{l}\text { Profil } \\
\text { lingkungan }\end{array}$ & $\begin{array}{lrr}\text { Adanya } & \text { studi } & \text { dampak } \\
\text { lingkungan } & \text { agar } & \text { dapat } \\
\text { dilakukan } & \text { pengawasan. } & \end{array}$ \\
\hline $\begin{array}{l}\text { Biaya } \\
\text { lingkungan }\end{array}$ & $\begin{array}{l}\text { Pengungkapan biaya untuk } \\
\text { merawat lingkungan }\end{array}$ \\
\hline $\begin{array}{l}\text { Piagam } \\
\text { lingkungan }\end{array}$ & 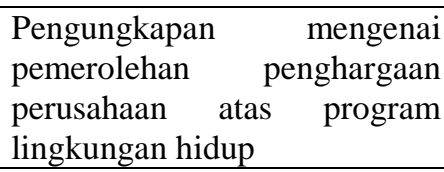 \\
\hline $\begin{array}{l}\text { Rencana } \\
\text { lingkungan } \\
\text { untuk masa } \\
\text { depan }\end{array}$ & $\begin{array}{l}\text { Pengungkapan perencanaan } \\
\text { masa depan, pembangunan, } \\
\text { aktivitas sistem manajemen } \\
\text { yang lebih baik }\end{array}$ \\
\hline
\end{tabular}

Sumber: Rohmah \& Wahyudi, 2015 
Kemudian nilai tersebut akan dihitung dengan penghitungan rasio sebagai berikut (Ainy \& Barokah, 2016):

$$
\begin{gathered}
\text { Pengungkapan } \\
\text { Lingkungan }
\end{gathered}=\frac{\text { Jumlah Item Pengungkapan Lingkungan yang Diungkapkan }}{\text { Jumlah Item Pengungkapan Lingkungan yang Ditetapkan }}
$$

Penelitian ini juga menambahkan variabel kontrol yang mampu memberikan perubahan yang mendukung pada hubungan variabel independen dan variabel dependen (Silalahi, 2015:189). Maksudnya, dengan adanya variabel kontrol, hasil pengujian yang diperoleh atas hubungan variabel dependen dan variabel independen dapat lebih optimal. Berdasarkan hal itu, peneliti yang mengharapkan hasil pengujian atas penelitian ini menjadi jelas dan optimal, maka peneliti menambahkan variabel kontrol yang berkaitan erat dengan variabel yang diteliti. Variabel kontrol yang dimaksud yaitu ukuran perusahaan dimana ukuran perusahaan yang digunakan, akan diukur dengan mengikuti pengukuran dari Wufron (2017) adalah sebagai berikut:

$$
\text { Ukuran Perusahaan }=\text { Ln }(\text { Total Aset })
$$

\section{Metode dan Sampel}

Pada penelitian ini, data yang digunakan yaitu data sekunder berupa dokumentasi dari laporan tahunan dan daftar peringkat PROPER dimana populasi yang digunakan yaitu seluruh perusahaan yang terdaftar di Bursa Efek Indonesia periode 2015-2018. Beberapa dari populasi tersebut akan dipilih sebagai sampel secara purposive sampling, dimana metode pemilihan sampel itu memiliki beberapa kriteria yang ditetapkan antara lain:

1. Perusahaan sektor non-keuangan yang memperoleh peringkat pada Program Peringkat Kinerja Perusahaan dalam Pengelolaan Lingkungan Hidup (PROPER) pada periode 2015-2017.

2. Perusahaan sektor non-keuangan yang mempublikasikan laporan tahunan dalam website Bursa Efek Indonesia periode 2015-2017.
3. Perusahaan sektor non-keuangan yang tidak mengalami kerugian dalam periode 2016-2018.

Sampel yang telah memenuhi kriteria diatas sejumlah 162 perusahaan, akan diuji dengan menggunakan program SPSS versi 23 dengan beberapa pengujian regresi berganda antara lain, uji statistik deskriptif, uji asumsi klasik, uji kelayakan model, dan uji hipotesis. Setelah diuji dengan pengujian regresi berganda, selanjutnya dilakukan uji sobel dan hasilnya di analisis dengan analisis jalur untuk mengetahui peran mediasi dari pengungkapan lingkungan. Berikut persamaan regresi yang digunakan:

$$
\begin{aligned}
& \mathrm{ROA}_{t+1}=\alpha_{0}+\alpha_{1} \cdot \mathrm{KL}+\alpha_{2} \cdot \operatorname{SIZE}+\varepsilon \ldots .(1) \\
& \mathrm{PL}=\beta_{0}+\beta_{1} \cdot \mathrm{KL}+\beta_{2} . \text { SIZE }+\mathrm{e} \ldots .(2) \\
& \mathrm{ROA}_{t+1}=\gamma_{0}+\gamma_{1} \cdot \mathrm{PL}+\gamma_{2} \cdot \text { SIZE }+\epsilon \ldots . .(3)
\end{aligned}
$$

Keterangan:

$$
\begin{aligned}
& \alpha_{0}, \beta_{0}, \gamma_{0}=\text { Konstanta } \\
& \alpha_{0}, \beta_{0}, \gamma_{0}, \alpha_{1}, \beta_{1}, \gamma_{1}=\text { Koefisien } \\
& \varepsilon, \mathrm{e}, \epsilon=\text { error } \\
& \mathrm{KL} \quad=\text { Kinerja Lingkungan } \\
& \mathrm{PL} \quad=\text { Pengungkapan } \\
& \text { Lingkungan } \\
& \text { SIZE = Ukuran Perusahaan } \\
& \mathrm{ROA}_{\mathrm{t}+1}=\text { Dimensi Sustainability } \\
& \text { Perusahaan }
\end{aligned}
$$

\section{Hasil Dan Pembahasan \\ Statistik Deskriptif, Uji Asumsi Klasik, Uji Kelayakan Model}

Pada penelitian ini, jumlah sampel yang digunakan sebanyak 162 perusahaan dimana perusahaan-perusahaan tersebut:

1. Perusahaan non keuangan yang terdaftar dalam BEI pada periode penelitian sebanyak 574 perusahaan.

2. Perusahaan yang memperoleh peringkat PROPER pada periode penelitian sebanyak 99 perusahaan.

3. Perusahaan yang mempublikasi laporan laporan tahunan pada periode penelitian di Bursa Efek Indonesia sebanyak 76 perusahaan.

4. Perusahaan yang tidak mengalami kerugian pada periode penelitian sebanyak 56 perusahaan. 
Jumlah sampel penelitian ini berbeda dengan jumlah sampel yang digunakan oleh Djuitaningsih dan Ristiawati (2011), Titisari dan Alviana (2012), serta Rohmah dan Wahyudin (2015). Pertama, ada penelitian Djuitaningsih dan Ristiawati (2011), jumlah sampel yang digunakan sebanyak 34 perusahaan selama tahun 2005 dan 2007 karena kriteria peneliti yang berbeda dengan penelitian ini yaitu penggunaan harga saham yang mendukung. Kedua, pada penelitian yang dilakukan oleh Titisari dan Alviana (2012), jumlah sampel yang digunakan sebanyak 90 perusahaan selama tahun 2007-2009 dengan kriteria yang berbeda yaitu mengharuskan perusahaan menerbitkan laporan keuangan dengan mata uang Rupiah. Ketiga, pada penelitian Rohmah dan Wahyudin (2015), jumlah sampel yang digunakan sebanyak 120 perusahaan selama periode2010-2012 dengan syarat yang berbeda dengan penelitian ini yaitu penggunaan perusahaan manufaktur saja.

Penelitian ini menggunakan 56 perusahaan per tahun atau total 162 perusahaan yang melalui pengujian pertama, yang menganalisis masing-masing variabel penelitian yaitu uji statistik deskriptif. Analisis dari uji statistik deskriptif menunjukan nilai minimum, maksimum, rata-rata, dan standar deviasi untuk masing-masing variabel. Pertama, dimensi sustainability perusahaan memperoleh nilai minimum sebesar 0,00023 ; nilai maksimum 0,30023 ; nilai rata-rata 0,07430 dan standar deviasinya 0,05946. Kedua, kinerja lingkungan memperoleh nilai minimum sebesar 2; nilai maksimum 5; nilai rata-rata 3,11 dan standar deviasinya 0,523. Ketiga, pengungkapan lingkungan memperoleh nilai minimum sebesar 0,11111 ; nilai maksimum 1; nilai rata-rata 0,68034 dan standar deviasinya 0,22961. Keempat, ukuran perusahaan memperoleh nilai minimum sebesar 26,21855; nilai maksimum 32,39255; nilai rata-rata 29,62306 dan standar deviasinya 1,44299.

Setelah melakukan pengujian statistik deskriptif, uji asumsi klasik seperti uji normalitas, uji heteroskedastisitas, dan uji multikolonieritas dilakukan. Hasil uji normalitas diperoleh bahwa masing-masing persamaan regresi telah terdistribusi normal, lolos uji heteroskedastisitas dan uji multikolonieritas, serta model regresi dinyatakan fit.

\section{Uji Hipotesis dan Analis Jalur}

Setelah menyelesaikan beberapa pengujian diatas, uji hipotesis dilakukan untuk mengetahui apakah hipotesis yang telah diajukan diterima atau ditolak dan berikut ringkasan model regresi:

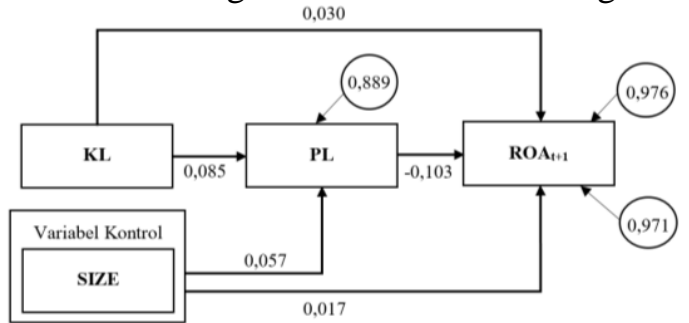

Sumber: data diolah (2020)

\section{Gambar 1. Model Regresi}

Gambar diatas menunjukan nilai yang dapat digunakan untuk melakukan pengujian Sobel. Hasil dari uji sobel disajikan dalam tabel dibawah ini:

Tabel 3.Hasil Uji Sobel

\begin{tabular}{|lll|}
\hline $\begin{array}{l}\text { Variabel } \\
\text { Independen }\end{array}$ & $\begin{array}{l}\text { Standard } \\
\text { Error }\end{array}$ & $\begin{array}{l}\text { Nilai t } \\
\text { Hitung }\end{array}$ \\
\hline KL & 0,005001 & $-6,60256$ \\
\hline
\end{tabular}

Sumber: data diolah (2020)

Berdasarkan tabel diatas, menunjukan bahwa nilai $\mathrm{t}$ hitung memenuhi syarat $\mathrm{t}$ tabel yaitu kurang dari -1,96. Hal ini membuktikan bahwa pengungkapan lingkungan mampu memediasi hubungan tidak langsung dari kinerja lingkungan terhadap dimensi sustainability perusahaan.

Pengungkapan lingkungan digunakan sebagai pemediasi dikarenakan hasil penelitian terdahulu yang belum konklusif pada hubungan langsung kinerja lingkungan terhadap dimensi sustainability perusahaan. Selain itu, hasil penelitian ini menunjukan bahwa kinerja lingkungan tidak mampu mempengaruhi dimensi sustainability secara langsung jika 
menggunakan tingkat signifikansi standar, namun, mampu mempengaruhi secara positif jika tingkat signifikansinya standar yang lebih besar. Hal ini mendorong penggunaan mediasi dari pengungkapan lingkungan karena pengaruh yang dapat diberikan kinerja lingkungan sangatlah kecil. Hal ini disebabkan karena kinerja lingkungan yang telah dilakukan perusahaan tidak mudah untuk diketahui oleh stakeholder secara detil, paling tidak mereka hanya mengetahui peringkat PROPER perusahaan dari Kementerian Lingkungan Hidup itu tergolong kinerja yang baik atau buruk.

Upaya yang dilakukan perusahaan untuk menyampaikan kinerja lingkungan yang telah dilakukan dan hasil dari kinerja tersebut menjadi lebih detil dan lebih luas, maka perlu adanya penggunaan pengungkapan lingkungan (Rohmah dan Wahyudin, 2015). Adanya pengungkapan lingkungan ini dapat dijadikan sebagai sarana penyampaian informasi perusahaan yang lebih luas kepada stakeholder. Luasnya pengungkapan lingkungan yang membahas mengenai kinerjanya ini mampu meningkatkan transparansi perusahaan. Semakin transparan suatu perusahaan, maka stakeholder semakin percaya dan hal ini mampu memberikan dampak positif pada dimensi sustainability perusahaan.

Hasil pengujian ini mendukung teori stakeholder dimana perusahaan yang melakukan kegiatan positif, bernilai dan bermoral seperti kinerja lingkungan dan pengungkapannya, maka stakeholder akan memperoleh informasi yang lebih luas mengenai perusahaan dalam kegiatan pengambilan keputusan. Dimensi sustainability yang diperoleh dari kegiatan lingkungan itu mampu memberikan kesejahteraan bagi stakeholder, baik pemerolehan dividen dan pembayaran kredit yang lebih terjamin, produk yang ramah lingkungan dan aman digunakan, bahkan adanya jaminan untuk tidak bangkrut dan melakukan pemutusan hubungan kerja bagi karyawan. Hasil penelitian ini juga mendukung teori legitimasi dimana perusahaan melakukan kegiatan bisnis sesuai dengan nilai-nilai keadilan terutama pada lingkungan.
Perusahaan yang peduli terhadap lingkungan, akan melakukan kinerja lingkungannya dengan baik. Kinerja lingkungan yang semakin baik, membuat perusahaan semakin percaya diri untuk melakukan pengungkapan lingkungan yang semakin luas. Pengungkapan lingkungan yang semakin luas itu mampu memberikan nilai positif dari stakeholder, sehingga para stakeholder akan merasa lebih yakin dan percaya pada perusahaan untuk memberikan legitimasi mereka. Legitimasi yang diperoleh mampu meningkatkan dimensi sustainability perusahaan karena perusahaan dipercaya telah melakukan kepedulian yang baik pada lingkungan sesuai nilai-nilai dalam kontrak sosial.

Penelitian ini sejalan dengan penelitian Rohmah dan Wahyudin (2015). Hasil yang diperoleh menunjukan bahwa kinerja lingkungan yang semula tidak berpengaruh terhadap hubungan langsung dengan dimensi sustainability, adanya peran mediasi dari pengungkapan lingkungan membuat kinerja lingkungan menjadi berpengaruh signifikan pada hubungan tidak langsung terhadap dimensi sustainability perusahaan.

\section{Simpulan}

Pengungkapan lingkungan yang digunakan sebagai pemediasi pada penelitian ini menunjukan adanya pengaruh kinerja lingkungan terhadap dimensi sustainability perusahaan melalui pengungkapan lingkungan tersebut. Hal ini dikarenakan kinerja lingkungan mampu mempengaruhi pengungkapan lingkungan secara positif, yang menunjukan bahwa kinerja lingkungan mampu diketahui oleh stakeholder dengan adanya pengungkapan lingkungan dan informasi ini dapat menimbulkan nilai positif bagi perusahaan dalam memperoleh legitimasi. Legitimasi yang diperoleh itulah yang mampu meningkatkan dimensi sustainability perusahaan.

Hasil dari penelitian ini memunculkan beberapa saran untuk penelitian berikutnya. Saran-saran yang dimaksud antara lain:

1. Penelitian berikutnya diharapkan menggunakan pengukuran kinerja 
lingkungan yang lebih komprehensif dan lebih riil daripada penelitian ini, misalnya menggunakan pemerataan nilai (dirata-rata) atau nilai yang paling banyak diperoleh pada perusahaan yang memiliki cabang banyak dan semua mengikuti PROPER.

2. Adanya perkembangan item-item pengungkapan lingkungan seperti penilaian emisi, energi dan sumber daya yang lebih detil, diharapkan mampu dijadikan sebagai pengukuran pengungkapan lingkungan yang lebih luas dibanding penelitian ini.

Penelitian ini juga tidak hanya menghasilkan saran untuk penelitian berikutnya, namun juga menghasilkan beberapa implikasi. Implikasi tersebut antara lain:

1. Bagi perusahaan non-keuangan yang sensitif terhadap lingkungan, yang mengharapkan dimensi sustainability perusahaan lebih terjamin, sebaiknya mulai melakukan pengelolaan lingkungan dengan baik misalnya melakukan kinerja lingkungan seperti melakukan pengelolaan limbah pabrik serta mengungkapkan hasil kinerja tersebut seluas-luasnya. Hal ini mampu memberikan informasi penting bagi stakeholder mengenai kepedulian perusahaan pada lingkungan, sehingga stakeholder semakin percaya atas transparansi perusahaan guna memperoleh legitimasi yang juga dapat berdampak baik pada dimensi sustainability

2. Bagi stakeholder dan pembuat kebijakan, informasi penting atas pengelolaan lingkungan baik hanya berbentuk peringkat atas kinerja lingkungan maupun pengungkapan lingkungannya, penting untuk diperhatikan. Hal ini dimaksudkan bahwa informasi tersebut dapat digunakan sebagai referensi tambahan dalam melakukan pengambilan keputusan serta pembentukan Undangundang mengenai lingkungan.

\section{Daftar Pustaka}

Ainy, R. N., dan Barokah, Z. (2016). Tata kelola perusahaan, pertanggungjawaban lingkungan, dan kinerja perusahaan: bukti empiris di Indonesia dan Malaysia. Simponsium Nasional Akuntansi XIX: Lampung, 1-22.

Amri, N. F. (4 September 2015). Teori Legitimasi. http://www.eakuntansi.com/2015/09/teorilegitimasi.html? $\mathrm{m}=1$

Burgwal, D. V. D., dan Vieira, R.J.O. (2014). Environmental Disclosure Determinants in Dutch Listed Companies. Scielo Revista Contabilidade \& Financas, 25(64), 60-78.

Dewi, R. K., Tamtomo, A.B., dan Velarosdela, R.N. (17 Februari 2019). Cek Fakta: 11 Perusahaan Tersangka Kebakaran Hutan Kena Sanksi Rp 18,3 triliun. https://nasional.kompas.com/read/201 9/02/17/22385631/cek-fakta-11perusahaan-tersangka-kebakaranhutan-kena-sanksi-rp-183-triliun.

Djuitaningsih, T., \& Ristiawati, E. E. (2011). Pengaruh Kinerja Lingkungan dan Kepemilikan Asing terhadap Kinerja Finansial Perusahaan. Jurnal Akuntansi Universitas Jember. 9(2), 31-54.

Fahmi, I. (2016). Pengantar Manajemen Sumber Daya Manusia, Mitra Wacana Media.

Freeman, R. E., Harrison, J.S., Wicks, A.C., Parmar, B., dan Colle, C.D. (2010). Stakeholder Theory The State Of The Art. Cambridge University.

Hadi, N. (2011). Corporate Social Responsibility. Graha Ilmu.

Halloriau. (23 Desember 2015). Terbukti Bakar Lahan, Izin HPH PT HSL Dicabut, PT SRL dan LIH Dibekukan. http://www.halloriau.com/read/hukri m-75317-2015-12-23-terbukti-bakarlahan-izin-hph-pt-hsl-dicabut-izin-ptsrl-dan-lih-dibekukan.html. 
Hartman, L. P., \& DesJardins, J. (2011). Etika Bisnis: Pengambilan Keputusan Untuk Integritas Pribadi Dan Tanggungjawab Sosial [Terjemahan]. Erlangga.

JATAM. (2019). Hentikan Perampasan Tanah oleh Tambang, Segera Cabut Izin Tambang di Pulau Wawonii, Sultra.

https://www.jatam.org/2019/07/12/he ntikan-perampasan-tanah-olehtambang-segera-cabut-izin-tambangdi-pulau-kecil-wawonii-sultra/.

Kusumo, G. (2018). Pencemara Limbah Pabrik: Menggugat Tanggungjawab Korporasi.

https://m.bisnis.com/amp/read/20180 309/250/747836/pencemaran-limbahpabrik-menggugat-tanggung-jawabkorporasi.

Nurleli., \& Faisal. (2016). Pengaruh Pengungkapan Informasi Lingkungan terhadap Kinerja Keuangan. Jurnal Kajian Akuntansi, 15(2), 31-54.

Pertiwi, I. (2015). Pengaruh Kinerja Lingkungan dan Pengungkapan Lingkungan terhadap Kinerja Keuangan (Studi Empiris pada Perusahaan Sektor Pertambangan yang terdaftar di Bursa Efek Indonesia Tahun 2010-2013). Skripsi Program Sarjana Universitas Islam Bandung.

http://repository.unisba.ac.id/handle/1 233456789/283.

Pratama, A. B., \& Kandi, R.D. (29 Oktober 2015). Hutan Terbakar: Izin Belasan Perusahaan Dibekukan dan Dicabut. https://m.cnnindonesia.com/nasional/ 20151029165529-12-88245/hutanterbakar-izin-belasan-perusahaandibekukan-dan-dicabut.

Program Penilaian Peringkat Kinerja Perusahaan dalam Pengelolaan Lingkungan. (2013). Peraturan Menteri Lingkungan Hidup Republik Indonesia nomor 6 tahun 2013 tentang Program Penilaian Peringkat Kinerja Perusahaan dalam Pengelolaan Lingkungan Hidup. http://proper.menlh.go.id.

Rohmah, I. L., \& Wahyudin, A. (2015). Pengaruh Environmental Performance terhadap Economic Performance dengan Environmental Disclosure sebagai Variabel Intervening. Accounting Analysis Journal, 4(1), 113.

Rudianto. (2013). Akuntansi Manajemen: Informasi Untuk Pengambilan Keputusan Strategis. Erlangga.

San, O. T., Ni, S.W., Heng, T.B., \& Huei, N.S. (2015). Influence of Environmental Disclosure on the Financial Performance of Public Listed Malaysian Manufacturing Companies. Asia-Pasific Management Accounting Journal, 10(1), 107-136.

Saputra, K. T. (19 Januari 2016). Perusahaan Dibekukan, 1400 Karyawan PT BMH dan PT SBA Terancam PHK. https://sumsel.tribunnews.com/amp/2 016/01/19/perusahaan-dibekukan1400-karyawan-pt-bmh-dan-pt-sbaterancam-phk.

Silalahi, U. (2015). Metode Penelitian Sosial Kuantitatif. Bandung: Refika Aditama.

Supriyadi. (2013). Konsep dan Model Pengukuran Corporate Sustainability: Sebuah Kajian Literatur. Study and Accounting Research, 10(3), 13-28.

Titisari, K. H., \& Alviana, K. (2012). Pengaruh Environmental Performance terhadap Economic Performance. Jurnal Akuntansi dan Keuangan Indonesia, 9(1), 56-67.

Tjahjono, M. E. S .(2013). Pengaruh Kinerja Lingkungan terhadap Nilai Perusahaan dan Kinerja Lingkungan. Jurnal Ekonomi, 4(1), 38-46.

Wufron. (2017). Pengaruh Ukuran Perusahaan terhadap Kinerja Keuangan serta Implikasinya terhadap Nilai Perusahaan pada Perusahaan Manufaktur yang Terdaftar di Bursa Efek Indonesia. Jurnal Wacana Ekonomi, 16(3), 2233. 
Versi Online: http://journal.ubm.ac.id/index.php/akuntansi-bisnis/ DOI: http://dx.doi.org/10.30813/jab.v13i2.1977

Hasil Penelitian
Jurnal Akuntansi Bisnis Vol.13 (No.2) : Hal.143-154 Th. 2020

ISSN: 1979-360X

E-ISSN: 2598-6767 